\title{
Bioindicators and environmental protection
}

\author{
I.M. Khanieva ${ }^{1, *}$, S.A. Bekuzarova ${ }^{2}$, R.Z. Abdulkhalikov ${ }^{1}$, A.L. Boziev ${ }^{1}$, and Yu.M. \\ Shogenov ${ }^{1}$ \\ ${ }^{1}$ Kabardino-Balkarian State Agrarian University, st. Ave. Lenin, 1B, 360030 Nalchik, Kabardino- \\ Balkarian Rep., Russia \\ ${ }^{2}$ Mountain State Agrarian University, st. Kirov, 37, 362040 Vladikavkaz, Rep. North Ossetia-Alania, \\ Russia
}

\begin{abstract}
The plants capable to occlude the maximum quantity of the heavy metals (HM) from soil solution are studied. Plants - indicators of accumulation of heavy metals are allocated, the new directions on decrease in toxicity of the soil are offered. For the purpose of studying of sorption abilities of bean herbs studied accumulation of heavy metals on phases of development of plants. Biological features bean which are capable to occlude heavy metals from the soil and air and by that to clear the polluted site are established. Plants can be the main bioindicators of impurity of soils. For a start in different environments the content of heavy metals by means of a method of chemical analysis control was defined, then compared maximum permissible concentration and drew a conclusion about danger of complex influence to the person and a biota For strengthening of sorption brought tseolitsoderzhashchy clays of Alanit of a local origin at crops of bean herbs. It is revealed that the maximum sorption abilities are found in plants vyazelya motley, and in mix with an amaranth, sowed cherezryadno the maximum effect on decrease in heavy metals on the polluted site is reached. A plant the ambrosia polynnolistny most of all accumulates doses of heavy metals.
\end{abstract}

\section{Introduction}

In recent decades, the soil has been contaminated with heavy metals and industrial emissions due to anthropogenic factors that affect the biosphere, water and land resources. [1].

The total power of sources of anthropogenic impact is much greater than the power of natural sources. So nitrogen oxide sources emit in the amount of 30 million tons of nitrogen $[2,3]$.

Lead, in the course of human exposure, enters the biosphere much more often than with natural pollution. The maximum damage to the environment can be caused by various types of pollution with heavy metals. In the air, industrial mega-centers are contaminated with heavy metals such as copper, lead, nickel, mercury, vanadium, zinc and chromium. It

\footnotetext{
*Corresponding author: imhanieva@mail.ru
} 
should be noted that such air pollution is included in various parts of plants and soil, and generally affects the environment. [4].

According to scientists, various soils are powerful filters against the flow of man-made substances, and a chemical barrier can be used to cleanse the biosphere. [4].

In the course of life, a person himself can be a source of high toxicity of substances in living nature that he synthesizes. Biological objects reliably control their actions. Many microorganisms, animals and plants are bioindicators. [7.8].Violation of the vital activity of various types of soil organisms is observed with the negative influence of heavy metals on some soil properties. For example, slowing down humification, and deterioration of soil properties. Heavy metals have a negative effect on metabolic links, in the course of their action on enzymes. In the case of replacement of the parent metal in the enzymes, the catalytic performance decreases. It should be noted that chloroplasts and mitochondria are disrupted due to the presence of heavy metals, namely at the subcellular level of ion transport and functions of cell membranes. [3, 4].

Many scientists are interested in biological nitrogen of leguminous crops in an environment of environmental stress [8,9]. How correctly they believe the use of leguminous crops restores soil fertility and reduces their toxicity. In our experiments we used alanite (zeolite-containing clay) and legumes (alfalfa, yellow and variegated sweet clover, sainfoin). Alanite is the newest sorbent. It allows you to improve soil fertility and take into account the parameters of the level of heavy metals in the soil.

At present, scientists from many countries are working on the study and determination of heavy metals in soils, their transformation and assessment of their amounts entering plants [Ajus DL, 2010, Juhasz AL, Waller N. 3 Lease C., Bentham R., Stewart R Pilot .. 2005] At the same time, there are few works devoted to the resistance of plant communities to chemical pollution.

Objects and research methods. The field experiment was carried out on the leached black soil of the educational and production complexes of the Kabardino-Balkarian State Agrarian University and the Gorsky State Agrarian University. The experimental plot of the CCP has the following characteristics: alkaline hydrolyzable nitrogen $-150 \mathrm{mg} / \mathrm{kg}$, the amount of humus in the arable layer 3.4\%, pH-6.5 - the reaction of the soil is neutral. Mobile phosphorus contains $30 \mathrm{mg}$ per $100 \mathrm{~g}$ of soil (average reserve) (according to Chirikov), exchangeable potassium - $80 \mathrm{mg}$ per $100 \mathrm{~g}$ (increased reserve). Leached heavy loamy chernozem with a physical clay content of $57.2 \%$, humus content in the Prigorodny region of the Republic of North Ossetia - Alania from 5 to $6.3 \%$, nitrogen reserves - $0.4 \%$, potassium - from $1.62-1.9 \%$, phosphorus - from 0.2 to $0.3 \%$, with the reaction of the soil environment from 5.48 to 6.92 .

4 variants of the experiment to reduce soil toxicity were laid. The first - control (without green mass), the second - with plowing of green mass in the flowering phase, the third - 5 days after mowing the green mass, plowing with alanite; fourth - plowing in 7-10 days after mowing. Basically, the experiments studied soil moisture, temperature conditions, and the content of heavy metals.

In our studies, the method of chemical-analytical control was used to determine HM, analyzes of the maximum permissible value of the safety level for humans and biota were carried out.

The content of heavy metals in the studied plants was determined on leached chernozem under the conditions of SKNIIGPSKh VN RAS, on the territory of the JSC "Electrozinc" plant and the educational and experimental field of the Kabardino-Balkarian State Agrarian University. The objects of study were leguminous herbs (alfalfa, goat's rue, clover, variegated elm, sainfoin), as well as sverbig and ragweed. Determined the content of heavy metals in the FGBU SAS "Kabardino-Balkarskaya".Alanite is a clay of local origin 
containing zeolite (steppe zone of the Republic of North Ossetia - Alania, Mozdok district). Alanite contains aluminum (A1203) - 16.5; sulfur, manganese, copper, zinc and phosphorus in an amount of 0.1-0.9\%., silicon (Si 02) - 52.8; iron (Fe203) 6.18; calcium (CaO) - 32.6.

The studied plants were identified as bioindicators, and they played an important role in restoring soil fertility, as well as in reducing the concentration of toxic substances in the soil.

Experimental results and discussion.

Perennial grasses in field studies are green fertilizers. During the research, we determined the content of manganese, iron, copper, cobalt, and zinc. We found that there is an increase in the HM content from the stemming phase to flowering. Their concentration for visel was: iron about $440 \mathrm{mg} / \mathrm{kg}$, cobalt more than $11 \mathrm{mg} / \mathrm{kg}$, manganese $700 \mathrm{mg} / \mathrm{kg}$, copper more than $15 \mathrm{mg} / \mathrm{kg}$ from the stage of steming to flowering.

It was found that the studied legumes accumulate in the soil a high concentration of zinc and mobile phosphates by the budding phase. In the course of the study, we found out that sainfoin carries up to $54 \mathrm{mg} / \mathrm{kg}$ of zinc and $32 \mathrm{mg} / \mathrm{kg}$ of copper, the visel takes out from the soil up to $43 \mathrm{mg} / \mathrm{kg}$ of copper and up to $45 \mathrm{mg} / \mathrm{kg}$ of zinc, alfalfa up to $99 \mathrm{mg} / \mathrm{kg}$ and $32 \mathrm{mg} / \mathrm{kg}$ of copper.

Alanite-zeolite-containing clay significantly absorbs radioactive substances and heavy metals. Interacting with the mown green mass of leguminous grasses, this clay removes cadmium, lead, zinc and copper. Thus, due to agricultural ores, the amount of metal particles in the soil is reduced, and heat is also released over several days. This method is effective on acidic soils where the PH is less than 5 units. The soil is well enriched with organic and mineral substances by the plowing of the studied clay together with the visel. Alanite absorbs moisture as a sorbent and also protects the mass from evaporation. It should be noted that alanite also retains the nitrogen released by the visel. Our research results are presented in table 1.

Table 1. Change in the content of heavy metals in the soil

\begin{tabular}{|c|c|c|c|c|c|}
\hline \multirow{2}{*}{ Experience options } & \multicolumn{5}{|c|}{ Heavy metals } \\
\hline & $\mathrm{Cu}$ & Co & $\mathbf{F e}$ & $\mathbf{P b}$ & Zn \\
\hline Plowing of visel mass (without alanite) - control & 83 & 0,40 & 614 & 5,7 & 94 \\
\hline Plowing of the mass of visel with alanite & 51 & 0,32 & 453 & 4,9 & 82 \\
\hline $\begin{array}{l}\text { Plowing of the mass of vazel with alanite, } 3-5 \text { days after } \\
\text { mowing (soil sampling } 2 \text { months after plowing) }\end{array}$ & 31 & 0,28 & 315 & 4,4 & 66 \\
\hline $\begin{array}{l}\text { Plowing the mass of vazel with alanite, } 7-10 \text { days after } \\
\text { mowing (soil sampling } 2 \text { months after plowing) is the best } \\
\text { option }\end{array}$ & 20 & 0,22 & 133 & 3,7 & 64 \\
\hline $\begin{array}{l}\text { Maximum allowable concentration } \\
\text { nineteen }\end{array}$ & 19 & 0,26 & 152 & 4,9 & 98 \\
\hline
\end{tabular}

As can be seen from Table 1, the volume of heavy metals decreases to the maximum permissible concentrations after plowing and mineralization of organic matter in the soil. Zeolite-containing clay alanite is effective for plowing, together with vasel as variegated as green manure. And vice versa, when plowing without alanite, a change in $\mathrm{pH}$ was noted, and then with alanite after mowing, the $\mathrm{pH}$ increased. Comparing the option without using alanite, the resulting figure is not higher than 4.84 . The $\mathrm{pH}$ value is 5.1 , the maximum when using visel and alanite after mowing. 
In a field experiment on the alanite application, a tendency for iron and copper to decrease (2-3 t / ha) was observed. At first, when plowing on the Vyazel + Alanite variant, the amount of copper was $52 \mathrm{mg} \mathrm{kg}$, then after a few days the indicator dropped to $42 \mathrm{mg} /$ $\mathrm{kg}$. After plowing after 5 days of Vyazel + Alanite, this indicator dropped to $31 \mathrm{mg} / \mathrm{kg}$, and after a week it was only $20 \mathrm{mg} / \mathrm{kg}$ of dry matter.

With the onset of the growing season of sainfoin, the number of metal forms changed for copper from 13 to 16 , zinc from 36 to 39, cobalt from 10 to 8, nickel from 14 to 16, iron from 410 to 390 and manganese from 700 to 670 .

Indicators of alfalfa in terms of the content of $\mathrm{HM}$ forms from the phases of stemming to flowering were: manganese from 580 to $710 \mathrm{mg} / \mathrm{kg}$. iron $360-440$, copper from 12.8 to 15.9, zinc from 40.1 to 43.2 , cobalt from 10 to 11.7 , nickel 13.5-16.2.

It should be noted that in the budding phase, the studied leguminous grasses in the soil accumulate the highest possible concentrations of the mobile form of copper, as well as zinc. We also found that sainfoin removes from the soil up to $54 \mathrm{mg} / \mathrm{kg}$ of copper, alfalfa up to $99.2 \mathrm{mg} / \mathrm{kg}$ of zinc and up to $32.4 \mathrm{~kg} / \mathrm{kg}$ of copper, variegated knot up to $43 \mathrm{mg} /$ $\mathrm{kg}$ of copper and up to $44.7 \mathrm{mg} / \mathrm{kg}$ of zinc.Vyazel has a number of advantages over other legumes.

As can be seen from Table 2, the concentration of heavy metals decreases due to the plowing of green manure (sprouted seeds of vasel and amaranth). They act as sorbents, neutralizing radionuclides and heavy metals in contaminated soil, thus purifying it through a chemical reaction.

Table 2. The content of heavy metals in the soil depending on the method of sowing green manure crops

\begin{tabular}{|c|c|c|c|c|c|}
\hline \multirow{2}{*}{ Experience options } & \multirow{2}{*}{$\begin{array}{c}\text { The content of } \\
\text { biological nitrogen } \\
\text { in the soil, kg / ha }\end{array}$} & \multicolumn{4}{|c|}{ Content in soil, $\mathrm{mg} / \mathrm{kg}$} \\
\cline { 3 - 6 } & 146 & 3,0 & 24 & 19,5 & 28,0 \\
\hline Amaranth & 160 & 3,7 & 32 & 15,2 & 31,5 \\
\hline Vyazel & 121 & 4,1 & 28 & 26,0 & 30,2 \\
\hline $\begin{array}{c}\text { Joint sowing of amaranth } \\
\text { and vyazel }\end{array}$ & 203 & 2,2 & 23 & 13,0 & 26,0 \\
\hline $\begin{array}{c}\text { Amaranth + vyazel, } \\
\text { sowing in rows in } \\
\text { separate strips }\end{array}$ & - & 6,7 & 34 & 19,7 & 31,5 \\
\hline $\begin{array}{c}\text { Maximum allowable } \\
\text { concentration }\end{array}$ & - & & & & \\
\hline
\end{tabular}

In the meantime, there is no need to worry about it.

On the variant of the combined sowing of amaranth and vazel, the lead content was more than $30 \mathrm{mg} / \mathrm{ha}$, and on the variant where the sowing was in successively separate strips, the lead level decreased to $26 \mathrm{mg} / \mathrm{ha}$. It is obvious that sowing in separate strips creates a certain microclimate for plants, which intensively absorb radionuclides and heavy metals. For other TMs, seeding through the rows was also the best.

Further, it should be noted that the variegated yogurt in the 2nd year gave a significant biomass of more than $12 \mathrm{t} / \mathrm{ha}$, while legumes - $10 \mathrm{t} / \mathrm{ha}$. The moisture content, in the variant when plowing the visel, was at the level of $20 \mathrm{~mm}$, in other variants with other crops, the indicators were lower by 1-2 $\mathrm{mm}$.

It is obvious that Vyazel, with its powerful root-sprouting system, as well as powerful aboveground and other biological features that is not inferior to it, is significantly superior to other crops.Based on the research results, we have compiled Table 3, where we give the 
sorption capacity of indicator plants for different territories. Obviously, they react differently to soil toxicity.

Table 3. HM content in the soil

\begin{tabular}{|c|c|c|c|c|c|c|c|c|c|c|}
\hline Name & $\begin{array}{c}\mathbf{Z n}, \\
\mathbf{m g} / \mathbf{k g}\end{array}$ & $\begin{array}{c}\text { Differen } \\
\text { ce with } \\
\text { MPC }\end{array}$ & $\begin{array}{c}\mathbf{C d}, \mathbf{m g} / \\
\mathbf{k g}\end{array}$ & $\begin{array}{c}\text { Difference } \\
\text { with MPC }\end{array}$ & $\begin{array}{c}\mathbf{C u}, \mathbf{m g} / \mathbf{k g} \\
\text { nith }\end{array}$ & $\begin{array}{c}\text { Differe } \\
\text { nce } \\
\text { with }\end{array}$ & $\begin{array}{c}\mathbf{F e}, \\
\mathbf{m g} / \mathbf{k g}\end{array}$ & $\begin{array}{c}\text { Difference } \\
\text { with MPC }\end{array}$ & $\begin{array}{c}\text { Ni, } \\
\mathbf{m g} / \\
\mathbf{k g}\end{array}$ & $\begin{array}{c}\text { Differenc } \\
\text { e with } \\
\text { MPC }\end{array}$ \\
\hline Clover & $\mathbf{1 8 , 1}$ & $-4,9$ & $\mathbf{0 , 9}$ & $-1,7$ & $\mathbf{5 , 8}$ & 2,8 & $\mathbf{5 9 1}$ & 359 & $\mathbf{3 , 8}$ & $-0,2$ \\
\hline Alfalfa & $\mathbf{1 6 , 8}$ & $-6,2$ & $\mathbf{0 , 8}$ & $-1,8$ & $\mathbf{6 , 3}$ & 3,3 & $\mathbf{5 6 2}$ & 330 & $\mathbf{4 , 1}$ & 0,1 \\
\hline $\begin{array}{c}\text { Sainfoin } \\
\mathbf{2 2 , 4}\end{array}$ & $-0,6$ & $\mathbf{0 , 9}$ & $-1,7$ & $\mathbf{5 , 7}$ & 2,7 & $\mathbf{5 4 2}$ & 310 & $\mathbf{4 , 7}$ & 0,7 \\
\hline $\begin{array}{c}\text { Goat's } \\
\text { rue }\end{array}$ & $\mathbf{1 7 , 8}$ & $-5,2$ & $\mathbf{1}$ & $-1,6$ & $\mathbf{5 , 7}$ & 2,7 & $\mathbf{4 5 3}$ & 221 & $\mathbf{4 , 7}$ & 0,7 \\
\hline $\begin{array}{c}\text { Vyazel } \\
\mathbf{1 9 , 6}\end{array}$ & $-3,4$ & $\mathbf{1 , 2}$ & $-1,4$ & $\mathbf{5 , 3}$ & 2,3 & $\mathbf{3 4 5}$ & 113 & $\mathbf{4 , 5}$ & 0,5 \\
\hline $\begin{array}{c}\text { Astragal } \\
\text { us K. }\end{array}$ & $\mathbf{1 8 , 5}$ & $-4,5$ & $\mathbf{1 , 2}$ & $-1,4$ & $\mathbf{5}$ & 2 & $\mathbf{3 4 5}$ & 113 & $\mathbf{4 , 3}$ & 0,3 \\
\hline $\begin{array}{c}\text { Astragal } \\
\text { us sl. }\end{array}$ & $\mathbf{2 1 , 7}$ & $-1,3$ & $\mathbf{1 , 3}$ & $-1,3$ & $\mathbf{4 , 9}$ & 1,9 & $\mathbf{4 6 3}$ & 231 & $\mathbf{4 , 6}$ & 0,6 \\
\hline $\begin{array}{c}\text { Sverbiga } \\
\mathbf{2 0 , 6}\end{array}$ & $-2,4$ & $\mathbf{1 , 1}$ & $-1,5$ & $\mathbf{5 , 7}$ & 2,7 & $\mathbf{5 7 2}$ & 340 & $\mathbf{5 , 2}$ & 1,2 \\
\hline $\begin{array}{c}\text { Ambrosi } \\
\text { a }\end{array}$ & $\mathbf{2 0 , 1}$ & $-2,9$ & $\mathbf{1 , 1}$ & $-1,5$ & $\mathbf{5}$ & 2 & $\mathbf{4 5 3}$ & 221 & $\mathbf{4 , 4}$ & 0,4 \\
\hline $\begin{array}{c}\text { Ambrosi } \\
\text { a JSC }\end{array}$ & $\mathbf{2 0 0 9 , 4}$ & 1986,4 & $\mathbf{1 7 , 3}$ & 14,7 & $\mathbf{8 6 , 7}$ & 83,7 & $\mathbf{2 3 7 5}$ & 2143 & $\mathbf{5 , 8}$ & 1,8 \\
\hline MPC & $\mathbf{2 3}$ & 0 & $\mathbf{2 , 6}$ & 0 & $\mathbf{3}$ & 0 & $\mathbf{2 3 2}$ & 0 & $\mathbf{4}$ & 0 \\
\hline
\end{tabular}

As can be seen from Table 3, for zinc and cadmium, there was no excess for all options except for the option with ragweed by Electrozinc JSC, where the excess was more than $1986 \mathrm{mg} / \mathrm{kg}$ for zinc and $14.7 \mathrm{mg} / \mathrm{ha}$ for cadmium. Also, for copper, the difference with MAC was $86.7 \mathrm{mg} / \mathrm{ha}$, for iron $-2143 \mathrm{mg} / \mathrm{kg}$ and nickel $-1.8 \mathrm{~m} / \mathrm{kg}$. The same picture is observed in ragweed taken for a sample on the territory of the educational and production complex of the Kabardino-Balkarian State Agrarian University for iron $221 \mathrm{mg} / \mathrm{kg}$. $4)$.

It was also revealed that the ragweed weed has the maximum sorption capacity (Table

Table 4. HM content in plants in the budding phase

\begin{tabular}{|c|c|c|c|c|c|c|c|c|c|c|c|c|}
\hline Name & $\begin{array}{c}\mathbf{Z n}, \mathbf{m g} / \mathbf{k} \\
\mathbf{g}\end{array}$ & $\begin{array}{c}\text { Differen } \\
\text { ce with } \\
\text { MPC }\end{array}$ & $\begin{array}{c}\mathbf{C d}, \mathbf{m} / \mathbf{k} \\
\mathbf{g}\end{array}$ & $\begin{array}{c}\text { Differen } \\
\text { ce with } \\
\text { MPC }\end{array}$ & $\begin{array}{c}\mathbf{C u}, \\
\mathbf{m g} / \mathbf{k} \\
\mathbf{g}\end{array}$ & $\begin{array}{c}\text { Differen } \\
\text { ce with } \\
\text { MPC }\end{array}$ & $\begin{array}{c}\mathbf{M n}, \\
\mathbf{m g} / \mathbf{k} \\
\mathbf{g}\end{array}$ & $\begin{array}{c}\text { Differen } \\
\text { ce with } \\
\text { MPC }\end{array}$ & $\begin{array}{c}\mathbf{F e}, \\
\mathbf{m g} / \mathbf{k g}\end{array}$ & $\begin{array}{c}\text { Differ } \\
\text { ence } \\
\text { with } \\
\text { MPC }\end{array}$ & $\begin{array}{c}\mathbf{N i} \\
\mathbf{m g} / \mathbf{k} \\
\mathbf{g}\end{array}$ & $\begin{array}{c}\text { Differ } \\
\text { ence } \\
\text { with } \\
\text { MPC }\end{array}$ \\
\hline Clover & $\begin{array}{c}\mathbf{2 9 , 1} \\
\mathbf{3}\end{array}$ & 3,03 & $\mathbf{0 , 3 8}$ & $-3,22$ & $\mathbf{3 , 6 8}$ & $-6,32$ & $\begin{array}{c}\mathbf{1 0 , 9} \\
\mathbf{4}\end{array}$ & $-27,06$ & $\mathbf{4 4 , 9 2}$ & - & $\mathbf{1 , 9 6}$ & $-0,54$ \\
\hline Alfalfa & $\begin{array}{c}\mathbf{3 3 , 2} \\
\mathbf{6}\end{array}$ & 7,16 & $\mathbf{0 , 4 9}$ & $-3,11$ & $\mathbf{3 , 8 8}$ & $-6,12$ & $\begin{array}{c}\mathbf{1 0 , 8} \\
\mathbf{5}\end{array}$ & $-27,15$ & $\mathbf{6 1 , 7 1}$ & - & $\mathbf{3 , 0 8}$ & $0,58,29$ \\
\hline Sainfoin & $\begin{array}{c}\mathbf{2 9 , 8} \\
\mathbf{1}\end{array}$ & 3,71 & $\mathbf{0 , 7 9}$ & $-2,81$ & $\mathbf{3}$ & -7 & $\begin{array}{c}\mathbf{2 7 , 1} \\
\mathbf{7}\end{array}$ & $-10,83$ & $\mathbf{1 1 8 , 1 9}$ & $\begin{array}{c}- \\
131,81\end{array}$ & $\mathbf{4 , 9 4}$ & 2,44 \\
\hline Goat's rue & $\begin{array}{c}\mathbf{3 2 , 4} \\
\mathbf{2}\end{array}$ & 6,32 & $\mathbf{0 , 5 9}$ & $-3,01$ & $\mathbf{5 , 5 7}$ & $-4,43$ & $\begin{array}{c}\mathbf{5 5 , 6} \\
\mathbf{6}\end{array}$ & 17,66 & $\mathbf{1 1 1 , 3}$ & $-138,7$ & $\mathbf{6 , 9 5}$ & 4,45 \\
\hline
\end{tabular}




\begin{tabular}{|c|c|c|c|c|c|c|c|c|c|c|c|c|}
\hline Vyazel & $\begin{array}{c}28,7 \\
8\end{array}$ & 2,68 & 0,3 & $-3,3$ & 2,69 & $-7,31$ & $\begin{array}{c}26,6 \\
8\end{array}$ & $-11,32$ & 85,01 & $\begin{array}{c}- \\
164,99 \\
\end{array}$ & 4,91 & 2,41 \\
\hline $\begin{array}{c}\text { Astragalus } \\
\mathrm{K} .\end{array}$ & 11,4 & $-14,7$ & $\mathbf{0 , 3 1}$ & $-3,29$ & 2,03 & $-7,97$ & 8,56 & $-29,44$ & 41,27 & $\begin{array}{c}- \\
208,73\end{array}$ & 4,56 & 2,06 \\
\hline $\begin{array}{c}\text { Astragalus } \\
\text { sl.. }\end{array}$ & $\begin{array}{c}46,7 \\
1\end{array}$ & 20,61 & 0,74 & $-2,86$ & 6,12 & $-3,88$ & $\begin{array}{c}54,1 \\
6\end{array}$ & 16,16 & 436,48 & 186,48 & 7,58 & 5,08 \\
\hline Sverbiga & 1,9 & $-24,2$ & 0,64 & $-2,96$ & 2,68 & $-7,32$ & $\begin{array}{c}30,4 \\
4\end{array}$ & $-7,56$ & 130,07 & $\begin{array}{c}- \\
119,93\end{array}$ & - & - \\
\hline $\begin{array}{c}\text { Ambrosia } \\
\text { M. }\end{array}$ & \begin{tabular}{|c|}
70,3 \\
2
\end{tabular} & 44,22 & 1,38 & $-2,22$ & 1,28 & $-8,72$ & 6,13 & $-31,87$ & 61,4 & $-188,6$ & 1,19 & $-1,31$ \\
\hline $\begin{array}{c}\text { Ambrosia } \\
\text { El. }\end{array}$ & $\begin{array}{c}472, \\
86\end{array}$ & 446,76 & 4,27 & 0,67 & $\begin{array}{c}14,1 \\
4\end{array}$ & 4,14 & $\begin{array}{c}14,7 \\
9\end{array}$ & $-23,21$ & 196,64 & $-53,36$ & 1,78 & $-0,72$ \\
\hline $\begin{array}{l}\text { Ambrosia } \\
\text { Highway. }\end{array}$ & $\begin{array}{c}412 \\
85\end{array}$ & 386,75 & 3,6 & 0 & 9,67 & $-0,33$ & $\begin{array}{c}18,7 \\
2\end{array}$ & $-19,28$ & 242,49 & $-7,51$ & 1,85 & $-0,65$ \\
\hline MPC & 26,1 & 0 & 3 & $-0,6$ & 10 & 0 & 38 & 0 & 250 & 0 & 2,5 & 0 \\
\hline
\end{tabular}

Table 5. HM content in plants in the flowering phase

\begin{tabular}{|c|c|c|c|c|c|c|c|c|c|c|c|c|}
\hline Name & $\begin{array}{c}\mathrm{Zn}, \\
\mathbf{m g} / \mathbf{k} \\
\mathrm{g}\end{array}$ & $\begin{array}{c}\text { Differe } \\
\text { nce } \\
\text { with } \\
\text { MPC }\end{array}$ & $\begin{array}{c}\text { Cd, } \\
\text { mg/ } \\
\text { kg }\end{array}$ & $\begin{array}{c}\text { Differe } \\
\text { nce } \\
\text { with } \\
\text { MPC }\end{array}$ & $\begin{array}{c}\mathrm{Cu}, \\
\mathbf{m g} / \\
\mathbf{k g}\end{array}$ & $\begin{array}{c}\text { Differe } \\
\text { nce } \\
\text { with } \\
\text { MPC }\end{array}$ & $\begin{array}{c}\mathrm{Mn}, \\
\mathbf{m g} / \\
\text { kg }\end{array}$ & $\begin{array}{c}\text { Differe } \\
\text { nce } \\
\text { with } \\
\text { MPC }\end{array}$ & $\begin{array}{c}\mathrm{Fe}, \\
\mathrm{mg} / \mathrm{k} \\
\mathrm{g}\end{array}$ & $\begin{array}{c}\text { Differe } \\
\text { nce } \\
\text { with } \\
\text { MPC } \\
\end{array}$ & $\begin{array}{c}\mathrm{Ni}, \\
\mathrm{mg} / \\
\mathrm{kg}\end{array}$ & $\begin{array}{c}\text { Differe } \\
\text { nce } \\
\text { with } \\
\text { MPC }\end{array}$ \\
\hline Clover & $\begin{array}{c}22,9 \\
8\end{array}$ & $-3,12$ & 0,36 & $-2,64$ & 4,23 & $-5,77$ & 9,02 & $-28,98$ & 91,05 & $\begin{array}{c}- \\
158,95\end{array}$ & 2,17 & $-0,33$ \\
\hline Alfalfa & $\begin{array}{c}14,6 \\
9\end{array}$ & $-11,41$ & 0,34 & $-2,66$ & 3,35 & $-6,65$ & $\begin{array}{c}15,1 \\
9\end{array}$ & $-22,81$ & 56,74 & $\begin{array}{c}- \\
193,26\end{array}$ & 1,68 & $-0,82$ \\
\hline Sainfoin & 33,9 & 7,8 & 0,48 & $-2,52$ & 2,75 & $-7,25$ & $\begin{array}{c}33,6 \\
5\end{array}$ & $-4,35$ & 52,37 & $\begin{array}{c}- \\
197,63\end{array}$ & 2,1 & $-0,4$ \\
\hline Goat's rue & 70,9 & 44,8 & 0,47 & $-2,53$ & 7,12 & $-2,88$ & $\begin{array}{c}15,8 \\
2\end{array}$ & $-22,18$ & $\begin{array}{c}113,9 \\
8\end{array}$ & $\begin{array}{c}- \\
136,02 \\
\end{array}$ & 4,29 & 1,79 \\
\hline Vyazel & $\begin{array}{c}53,8 \\
1 \\
\end{array}$ & 27,71 & 0,56 & $-2,44$ & 5,58 & $-4,42$ & 52,5 & 14,5 & 88,4 & $-161,6$ & 4,81 & 2,31 \\
\hline $\begin{array}{c}\text { Astragalus } \\
\mathrm{K} .\end{array}$ & 40,8 & 14,7 & 0,67 & $-2,33$ & 5,58 & $-4,42$ & $\begin{array}{c}20,0 \\
6\end{array}$ & $-17,94$ & 69,8 & $-180,2$ & 9,07 & 6,57 \\
\hline $\begin{array}{l}\text { Astragalus } \\
\text { sl. }\end{array}$ & $\begin{array}{c}43,6 \\
7\end{array}$ & 17,57 & 0,67 & $-2,33$ & 5,64 & $-4,36$ & 61,4 & 23,4 & \begin{tabular}{|c|}
110,4 \\
5
\end{tabular} & 139,55 & 3,37 & 0,87 \\
\hline Sverbiga & $\begin{array}{c}41,0 \\
3\end{array}$ & 14,93 & 0,47 & $-2,53$ & 2,13 & $-7,87$ & $\begin{array}{c}16,8 \\
4\end{array}$ & $-21,16$ & 87,77 & $\begin{array}{c}- \\
162,23\end{array}$ & 1,42 & $-1,08$ \\
\hline $\begin{array}{c}\text { Ambrosia } \\
\text { M. }\end{array}$ & $\begin{array}{c}123, \\
03\end{array}$ & 96,93 & 0,93 & $-2,07$ & 5,25 & $-4,75$ & 17,7 & $-20,3$ & $\begin{array}{c}175,5 \\
5\end{array}$ & $-74,45$ & 2,25 & $-0,25$ \\
\hline $\begin{array}{c}\text { Ambrosia } \\
\text { El. }\end{array}$ & \begin{tabular}{|c|}
520, \\
36
\end{tabular} & 494,26 & 2,32 & $-0,68$ & $\begin{array}{c}12,0 \\
4\end{array}$ & 2,04 & $\begin{array}{c}10,7 \\
6 \\
\end{array}$ & $-27,24$ & $\begin{array}{c}276,6 \\
4\end{array}$ & 26,64 & 1,67 & $-0,83$ \\
\hline MPC & 26,1 & 0 & 3 & 0 & 10 & 0 & 38 & 0 & 250 & 0 & 2,5 & 0 \\
\hline
\end{tabular}

The highest zinc content in the green mass of the ragweed weed was noted along the highway and in the area of the plant, as evidenced by the analysis of the data obtained (Table 5). 


\section{Conclusion}

1. Leguminous grasses accumulate more heavy metals from the stalking phase to the budding and flowering phases, especially the variegated elm from the soil, thereby contributes to a decrease in the content of heavy metals in the arable layer and restores the physicochemical parameters of the soil.

2. Zeolite-containing clay Alanite significantly reduces heavy metals in the soil. When plowed together with leguminous herbs, it increases the accumulation of organic matter and their mineralization.

3. As established in our research, sowing of variegated and amaranth visel reliably restores soil fertility.

5. The greatest accumulation of heavy metals in the studied crops was observed in the area of highways and JSC "Electrozinc".

\section{References}

1. Biological control of the environment, Genetic monitoring, 136 (2010)

2. Biological control of the environment, Bioindication and biotesting, 156 (2010)

3. N.Yu. Welts, Invention «Method for assessing environmental pollution with heavy metals», Patent No. 2257597 dated July 27, IPC: G01V9 / 00, G01 33/48 (2005)

4. V.B. Zaalishvili, R.V. Osikina, Invention «Method for assessing the ecological state of the territory» Patent No. 2375869 dated 20.12., IPC: AO1G 23/00 (2009)

5. K.E. Sokaev, G.P. Khubaeva, Ecology of the natural environment of the city of Vladikavkaz and its suburbs, 207 (2014)

6. I.M. Khanieva, S.A. Bekuzarova, M.Kh. Khaniev, «A method for reducing the radioactivity of soils» Patent No. 258027, published on June 20, IPC B09C1 / 00 (2016)

7. I.M. Khanieva, The innovative paradigm of the development of natural sciences, Monograph, 38 (2020)

8. B.G. Tsugkiev, T.B. Basaev, L.Ch. Gagieva, Ecological methods for neutralizing heavy metals in the soil. Agriculture, 1, 15 (2004)

9. D.L. Ajus, Developmental instability, fluctuating asymmetry and their relation to stress, Vignette in M.C. Newman. Fundamentals in Ecotoxicology, 3rd edition, 327 (2010)

10. A. L. Juhasz, N.3 Waller, C. Lease, R. Bentham, R. Stewart, Bioremed journals, 9, $141(2005)$ 